\title{
Three new Luticola D.G.Mann (Bacillariophyta) species from Rapa Nui (Easter Island) found in terrestrial diatom assemblages dominated by widely distributed taxa
}

\author{
Lukasz Peszek $^{\text {Corresp., } 1}{ }^{,}$, Mateusz Rybak ${ }^{1}$, Horst Lange-Bertalot ${ }^{2}{ }$ John Patrick Kociolek $^{3}{ }$ Andrzej Witkowski $^{4}$ \\ ${ }^{1}$ Department of Agroecology, Institute of Agricultural Sciences, Land Management and Environmental Protection, University of Rzeszów, Rzeszów, Poland \\ 2 Institute of Ecology, Evolution and Diversity, Goethe University, Frankfurt am Main, Germany \\ 3 Museum of Natural History and Department of Ecology and Evolutionary Biology, University of Colorado, Boulder, Colorado, United States \\ 4 Institute of Marine and Environmental Sciences, University of Szczecin, Szczecin, Poland \\ Corresponding Author: Łukasz Peszek \\ Email address: Ipeszek@ur.edu.pl
}

Background. Rapa Nui (Easter Island = Isla de Pasqua) is of volcanic origin, best known for about 900 man-made stone statues known as moai. It is one of the most isolated inhabited islands on Earth and studies on the diatoms of Rapa Nui are very few. Methods. Light (LM) and electron microscopic (SEM) observations of a single sample collected from Rapa Nui are presented. The samples (mix of soil and organic detritus) were collected from ground of cave entrance. Results. The samples were characterized by low diatom diversity and strongly dominated by terrestrial (soil) forms. Among the taxa present in the material studied were cosmopolitan forms of the genera Humidophila, Nitzschia, Diadesmis, Angusticopula, Orthoseira, Tryblionella and Luticola. Whereas most of taxa of the enumerated genera were identifiable, only one among four Luticola species distinguished in the samples studied was identified. This taxon was L. ectorii, a cosmopolitan species known previously from South America (Brazil) and Asia (China). The three remaining species could not be assigned to any established species. Therefore, based on external and internal morphological features from light and scanning electron microscopic analysis, we describe here three species new to science, including: $L$. georgzizkae, L. rapanuiensis and L. moaiorum. All three taxa new to science are compared to established Luticola species and their significance for the global distribution of the genus is discussed. 


\section{Three new Luticola D.G.Mann (Bacillariophyta) species}

\section{2 from Rapa Nui (Easter Island) found in terrestrial diatom}

\section{3 assemblages dominated by widely distributed taxa}

4

5

6

7 Witkowski ${ }^{4}$

8

30

31

${ }^{1}$ Department of Agroecology, Institute of Agricultural Sciences, Land Management and Environmental Protection, University of Rzeszów, ul. Ćwiklińskiej 1a, 35-601 Rzeszów, Poland ${ }^{2}$ Goethe University, Institute of Ecology, Evolution and Diversity, Frankfurt am Main, Germany ${ }^{3}$ Museum of Natural History and Department of Ecology and Evolutionary Biology University of Colorado, Boulder, Colorado, 80309 USA

${ }^{4}$ University of Szczecin, Institute of Marine and Environmental Sciences, Mickiewicza 18, 70 383 Szczecin, Mickiewicza 16a, 70-383 Szczecin, Poland

Corresponding Author:

Łukasz Peszek ${ }^{1}$

Ćwiklińskiej 1a, Rzeszów, Podkarpackie, 35-601 Rzeszów, Poland

Email address: 1peszek@ur.edu.pl 
32 Background. Rapa Nui (Easter Island = Isla de Pasqua) is of volcanic origin, best known for

33 about 900 man-made stone statues known as moai. It is one of the most isolated inhabited islands 34 on Earth and studies on the diatoms of Rapa Nui are very few.

35 Methods. Light (LM) and electron microscopic (SEM) observations of a single sample collected 36 from Rapa Nui are presented. The samples (mix of soil and organic detritus) were collected from 37 ground of cave entrance.

Results. The samples were characterized by low diatom diversity and strongly dominated by terrestrial (soil) forms. Among the taxa present in the material studied were cosmopolitan forms of the genera Humidophila, Nitzschia, Diadesmis, Angusticopula, Orthoseira, Tryblionella and Luticola. Whereas most of taxa of the enumerated genera were identifiable, only one among four Luticola species distinguished in the samples studied was identified. This taxon was L. ectorii, a cosmopolitan species known previously from South America (Brazil) and Asia (China). The three remaining species could not be assigned to any established species. Therefore, based on external and internal morphological features from light and scanning electron microscopic analysis, we describe here three species new to science, including: L. georgzizkae, L. rapanuiensis and L. moaiorum. All three taxa new to science are compared to established Luticola species and their significance for the global distribution of the genus is discussed.

\section{Introduction}

Studies on the diatoms of Rapa Nui are very few (e.g. Cocquyt et al., 1991). These reports have documented species composition of the diatom assemblages from crater lakes and water pools near the coast. These studies used light microscopy to identify 70 taxa in freshwater lakes and brackish water pools near the coast. During these studies no new taxa were described and most of the identified taxa were considered as cosmopolitan.

From marine waters around Rapa Nui the new diatom genus and species Florella pascuensis Navarro was also described at water depths of 30-40 m and epiphytic on Halimeda sp. and Padina sp. (Navarro, 2002). Diatoms from a core taken in an inland lake have been studied along with other proxies by Dumont et al. (1998) to reconstruct an arrival of alien societies and their impact on the famous moai quarry (e.g. Hamilton, 2013).

Terrestrial habitats are places of characteristic diatom floras, dominated by resistant species which are able to thrive in conditions of limited water availability. Among such taxa are 
63 representatives of Luticola D.G. Mann (e.g. Round et al. 1990, Levkov et al., 2013). Luticola was

64 established to accommodate species included in Naviculae sect. Punctatae. Luticola

65

66

67

68

69

70

71

72

73

74

75

76

77

78

79

80

81

82

83

84

85

86

87

88

89

90

91

92

93

mutica (Kütz.) D.G.Mann was selected as the generitype. Luticola is one of the few diatom genera which earned an extensive treatise with LM and scanning electron microscopy (SEM) (Levkov et al., 2013). These authors estimated the diversity of the genus to be ca. 200 taxa. Algaebase lists 239 species names in the database at present, as well as 23 infraspecific names. Of the species names, 236 have been flagged as accepted taxonomically on the basis of the listed literature under the species name (M.D. Guiry in Guiry \& Guiry, 2020). The list shall be soon expanded with several new species very recently described from Western Ghats in India (Lokhande et al., 2020). The genus name was derived from Latin word "Lutum" meaning "mud" hence Luticola means mud dwelling (Round et al., 1990). Indeed, many of the Luticola species, including the generitype L. mutica, are inhabitants of tidal mudflats and characterized by high tolerance of inorganic and organic pollutants therefore indicative of poor water quality (LangeBertalot, 1977; Lange-Bertalot et al., 2017). However, with recent discoveries and newly established taxa, some Luticola species may be characteristic of pristine lacustrine, swamp, riverine, estuarine, mangrove and terrestrial (soil) microhabitats (Levkov et al., 2013; Van de Vijver et al., 2002; Bąk et al., 2017, 2019; Chattova et al., 2017; Simonato et al., 2020; Lokhande et al., 2020).

Likewise, the biogeography of Luticola is interesting. Luticola taxa have been chiefly distributed in the Holarctic plant realm, especially in Eurasia (Navicula mutica Kützing) and North America (Hustedt, 1962; Patrick \& Reimer, 1966; Krammer \& Lange-Bertalot, 1988). A number of taxa have been described and known to occur or cited in the tropics (Hustedt, 1937-1939) or in high latitudes of the Southern Hemisphere (Heiden \& Kolbe, 1928; Giffen, 1966; Cholnoky, 1954). A change in our understanding of the distribution of Luticola taxa is occurred in the mid-1990s and a wealth of Luticola have been described as new to science from tropical rainforests of South America (Metzeltin \& Lange-Bertalot, 1998; Metzeltin \& Lange-Bertalot, 2005; Bustos et al., 2017; Straube et al., 2017; Da Silva-Lehmkuhl et al., 2019), in the Andes (Rumrich et al., 2000; Simonato et al., 2020) and in South-East Asia (e.g. Glushchenko \& Kulikovskiy, 2015;

Glushchenko et al., 2018). High diversity of Luticola also has been observed in Antarctica and Sub-Antarctic Islands (Van de Vijver et al., 2002; Kopalova et al., 2011; Chattova et al., 2017; Kochman-Kędziora et al., 2020). The discussion on this biogeographic phenomenon has been

PeerJ reviewing PDF | (2020:11:55610:1:1:NEW 16 Feb 2021) 
94 recently published by Kociolek et al. (2017). In addition, Simonato et al. (2020) recognized

95 different morphological groups in the genus, and noted their biogeographic distributions,

96 including a small group of species differentiated from all others that are known only from South

97 America.

98 The aim of our study was to analyze the species diversity in a set of three samples taken from 99 terrestrial (cave) habitats from the Rapa Nui using high resolution LM and field emission SEM.

100 Although only one sample turned out to be rich in diatoms with moderate species diversity, and 101 many of the taxa present were cosmopolitan forms known from terrestrial and aerophytic 102 habitats world-wide, with a few typical of South America. Of the Luticola species present in this 103 sample, we recognized four species, three of which we describe here as new to science. In this 104 way we confirm the special status of Luticola in the Southern Hemisphere and at Rapa Nui as an 105 area of diversity for this genus.

106

\section{Materials \& Methods}

108 Study area

109 Rapa Nui (Easter Island = Isla de Pasqua) is located in the southeastern Pacific Ocean and is a 110 special territory of Chile located $3580 \mathrm{~km}$ off the coast of this country. It is one of the most 111 isolated inhabited islands on Earth. The island is $21 \mathrm{~km}$ wide, with an area of $166 \mathrm{~km}^{2}$. The 112 climate on Rapa Nui is classified as subtropical marine. Annual mean temperature is $20.8^{\circ} \mathrm{C}$ with 113 an annual average daily variation of $6.3^{\circ} \mathrm{C}$. Annual mean precipitation recorded is nearly 1217 $114 \mathrm{~mm}$ (Quilliam et al., 2014). Because of its volcanic origin, Rapa Nui has a large number of caves 115 (Ciszewski et al., 2009). The porous nature of the lava, as well as the island's caves, prevents the 116 formation of watercourses, since rainwater is immediately absorbed into the ground. However, a 117 few springs are found near the north coast. There are only three lakes where rainwater gathers:

118 the craters of Rano Kau, Rano Raraku and Rano Aroi (Charola, 1994)

119 Rapa Nui is best known for about 900 man-made stone statues known as moai. The vascular 120 plant flora of Rapa Nui is extremely poor compared to other tropical islands, reflecting its young 121 geological age, small size, and high degree of isolation (Aldén, 1990). Nearly 90\% of the 122 territory is covered by herbaceous vegetation, with species of Poaceae (grasses); most of them 123 are alien (Etienne et al., 1983; Finot et al., 2015). 23\% of vascular flora is comprised of endemic 124 species, and 20 species are native, 10 of which are endemic but have disappeared or are 
125 endangered (Dubois et al., 2013). Zizka (1991) identified 179 species of flowering plants in total.

126 It seems that the original vegetation of the island was represented by palm-dominated forests but 127 was replaced by a large number of introduced species that became naturalized (Rull et al., 2010).

128 The flora of Rapa Nui is particularly poor due to the human activity, including deforestation, 129 introduction of the Polynesian rat, fire and agriculture. Deforestation would have occurred about 130 AD 1000-1200 or even 600 years later (Mann et al., 2008). Around AD 1650 social collapse of 131 Rapa Nui occurred that was accompanied by warfare, a crash in population size, and cultural 132 changes (Diamond, 2005). The history of island has been interpreted in different ways. One 133 interpretation suggests an uncontrolled growth of the human population resulted in the

134 destruction of the natural vegetation and led to near extinction of inhabitants (Diamond, 2005). A 135 second theory suggests disease due to microorganisms could have been introduced by European 136 arrivals (Hunt, 2007). A third scenario suggests introduction of the rapidly-reproducing rat 137 (Rattus exulans Peale) may have done more damage to the native plants and animals than the 138 Polynesians (Towns et al., 2006). A fourth interpretation of the disaster on Rapa Nui holds that 139 environmental changes beyond the control of humans triggered the societal collapse (Diamond, 140 2005).

\section{Sampling}

143 The samples were collected from cave number 436, on 30 April 1988 by Professor Dr. Georg 144 Zizka during his work on flowering plants of Rapa Nui project (see Zizka 1991) (Fig. 1).

145 Samples in the form of soil and organic detritus were collected from the ground of the cave 146 entrance. The sampling site was exposed to natural light. Samples composed of soil mixed with 147 organic matter were boiled with $30 \%$ hydrogen peroxide $\left(\mathrm{H}_{2} \mathrm{O}_{2}\right)$ for a few hours at $150^{\circ} \mathrm{C}$ and 148 then rinsed and settled 5 times with deionized water. The resulting cleaned diatom material was 149 pipetted onto coverslips and dried, and then mounted on glass slides using Naphrax ${ }^{\circledR}$ mounting 150 medium (Brunel Microscopes Ltd, Wiltshire, U.K.). LM observations of the cleaned material 151 were made with a Zeiss Axio Imager A2 and Zeiss Axio Imager M2 (Carl Zeiss, Jena, Germany) 152 using a $\times 100$ Plan Apochromatic oil immersion objective $(\mathrm{NA}=1.46)$ equipped with Differential 153 Interference Contrast (DIC). Diatom images were captured with a Zeiss AxioCam ICc5 camera 154 (Jena, Germany). 300 diatom valves were counted for to establish diatom species composition in 155 the samples. For SEM examination, a few drops of cleaned material were put onto Whatman 
156 Nuclepore polycarbonate membrane filters (Fisher Scientific, Schwerte, Germany). Once dried,

157 the membranes were mounted onto aluminum stubs and coated with $20 \mathrm{~nm}$ of gold. SEM

158 observations were performed at the University of Rzeszów, using a Hitachi SEM SU8010.

159 Diatom terminology follows Round et al. (1990) and Levkov et al. (2013).

160

161

\section{Results}

162 From three collected samples, one of them completely barren, the second one only with few

163

164

165

166

167

168

169

170

171

172

173

174

175

176

177

178

179

180

181

182

183

184 185

diatom valves and the third was abundant in diatoms. In this particular sample besides the newlydescribed Luticola species represented by numerous well-established populations, we also identified 24 diatom species. The genus Luticola was represented in this small sample by four species, three of which are described herein as new to science and Luticola ectorii Levkov, Metzeltin \& Pavlov (Levkov et al., 2013).

\section{Novel taxa - diagnosis}

Luticola georgzizkae sp. nov. Witkowski, Lange-Bertalot, M. Rybak \& Peszek (Fig. 2).

Light microscopy: Valves rhombic to rhombic-lanceolate in larger specimens, with slightly undulate margins (Fig 2A-N), usually bearing a row of distinct spines (Fig. 2B, E, G). Valve length 8.3-35.2 $\mu \mathrm{m}$, width 6.4-10.3 $\mu \mathrm{m}$. Axial area narrow and linear. Central area rectangular bordered by single row of areolae. Transapical striae clearly punctate, radiate, 16-19 in $10 \mu \mathrm{m}$, contain 3-4 areolae per stria.

Scanning electron microscopy: Externally, raphe linear not reaching the valve apices, especially in large specimens, with external proximal endings slightly deflected to the side opposite the stigma (Fig. 2O-T, V), distal raphe endings straight to curved slightly in the same direction as the proximal ends (Fig. 2O-S, U, V). Areolae rounded to transapically elongate, radiate (Fig. 2T, V). Transapically elongated stigma located close to valve margin in the expanded central area (Fig. 2S, T, V). The external surface of the valve makes it possible to distinguish two morphotypes. First with large marginal spines, small spines on whole valve surface, deeply positioned areolae and shorter raphe (Fig. 2O-R). The second, without marginal spines and with smooth, flat valve surface and raphe slit which almost reach the valve apices (Fig. 2S).

PeerJ reviewing PDF | (2020:11:55610:1:1:NEW 16 Feb 2021) 
186 Internally, raphe branches simple and straight, proximal ends slightly deflected to stigma side 187 (Fig. 2W-Z). Small stigma positioned close to the valve margin with a circular and lipped 188 structure without a distinct opening (Fig. 2Z). Areolae variable in shape, single row of areolae 189 positioned also on valve mantle (Fig. 2Y, Z). Areolae occluded by hymenes, near the central area 190 separated, becoming a continuous strip near valve apices (Fig. 2X, Y). Copulae opened with 191 perforations and covered by small silica granules (Fig. 2AC). Marginal channel tube-like, located 192 on valve face/mantle junction, internally occluded with hymenes (fig. 2Z), widened in the central 193 valve part, on the side opposite to stigma (Fig. 2X).

194 For morphometric description 30 valves were analyzed under LM, and 15 valves under SEM. 195

196 Type locality: Type: Rapa Nui, cave interior, Coordinates: 276'42"S 109²4'14"W, collected on 197 30.04.1988 by Prof. Georg Zizka from Senckenberg Institute, Frankfurt am Main, Germany. 198 Holotype: holotype designated here: slide SZCZ 20608 (Fig. 2D) in the collection of Andrzej 199 Witkowski at the University of Szczecin.

200 Isotype: slide number 2020/11 in the Diatom Collection of the Institute of Agricultural Sciences, 201 Land Management and Environmental Protection at the University of Rzeszów.

202 Etymology: The new species is named in honor of Professor Dr. Georg Zizka for his scientific 203 achievements in Botany.

204

205 Luticola rapanuiensis sp. nov. M. Rybak, Peszek, Witkowski \& Lange-Bertalot (Fig. 3).

206 Light microscopy: Valves rhombic to elliptical with obtusely rounded apices. Valve length 5.2$20715.9 \mu \mathrm{m}, 4.3-7.6 \mu \mathrm{m}$ in width. Axial area narrow and linear, central area bow-tie shaped and 208 bordered by 3-4 small areolae. Transapical striae radiate, 16-19 in $10 \mu \mathrm{m}$, clearly punctate, 209 composed of 2-3(4) areola per stria (Fig. 3A-P).

210

211 Scanning electron microscopy: Externally, raphe straight to slightly bent, contained within a 212 narrow axial area (Fig. 3Q-V). External proximal raphe ends curved towards the stigma, which 213 is small (Fig. 3W), and positioned near the margin in the expanded central area, continuing with 214 irregular shallow grooves often conjoined with areolae which bordered central area (Fig. 3U). 215 Ghost areolae often observed within the central area (Fig. 3W). Distal raphe ends are curved to 216 tightly hooked in the same direction as the proximal ends (Fig. 3W, Y). Striae strongly radiate, 
217 composed of 2-4 rounded areolae (Fig. 3Q-V). On valve face/mantle junction siliceous ridges 218 are present (Fig. 3X, Y).

219

220

221

Internally, raphe simple and straight with proximal ends terminating in a small, internally-

222 elevated central nodule; distal endings terminate simply (Fig. 3AA, AB). Areolae occluded by 223 hymenes and not forming continuous strip across valve (Fig. 3AA). Stigma appears as a simple sunken opening (Fig. 2AB). Marginal channel, located on valve face/mantle junction, narrow and internally occluded with hymenes (Fig. 3AA). For morphometric description 40 valves were analyzed under LM, and 25 valves under. Type locality: Rapa Nui, cave interior, Coordinates: $27^{\circ} 6^{\prime} 42^{\prime \prime S} 109^{\circ} 24^{\prime} 14^{\prime \prime} \mathrm{W}$, collected on 30.04.1988 by Prof. Georg Zizka from Senckenberg Institute, Frankfurt am Main, Germany. Holotype: holotype designated here: slide SZCZ20608 (Fig. 3H) in the collection of Andrzej Witkowski at the Institute of Marine and Environmental Sciences, University of Szczecin.

Isotype: slide number 2020/11 in the Diatom Collection of the Institute of Agricultural Sciences, Land Management and Environmental Protection at the University of Rzeszów. Etymology: The species name refers to the island (being locus typicus) in the native language

Luticola moaiorum sp. nov. Peszek, M. Rybak, Witkowski \& Lange-Bertalot (Fig. 4). apices. Valve length 8.9-24.3 $\mu \mathrm{m}$, width 4.3-7.9 $\mu \mathrm{m}$ in width. Axial area narrow and linear, central area bow-tie-shaped bordered by a solitary row of areolae. Transapical striae radiate becoming strongly radiate near apices (Fig. 4A-N), 18-24 in $10 \mu \mathrm{m}$ with 3-4 areola per stria $(14-18$ in $10 \mu \mathrm{m})$.

242 Scanning electron microscopy: Externally, raphe branches straight (Fig. 4O-T), with proximal 243 raphe endings distinctly bent to the side opposite stigma (Fig. 4O-T, U), distal raphe endings 244 also bent to the side opposite to stigma (Fig. 4O-T, V). Areolae rounded to slightly elongated, 245 radiate, 3-4 per stria (Fig. 4U, V), with a single row of areolae present on valve mantle (Fig. 4O, $246 \mathrm{R}, \mathrm{Q})$ Siliceous ridges present on valve face/mantle conjunction in almost half of observed 247 specimens (Fig. 4V). 
248

249 Internally, raphe simple and straight (Fig. 4W, X). Areolae covered by a single expansive

250 hymenes forming continuous strips (Fig. 4Y). Stigma located in central area, about mid-way

251 between the valve margin and the center, with a small C-shaped opening lipped structure (Fig.

252 4Y, Z). Marginal channel, located on valve face/mantle junction, narrow and occluded with

253 hymenes (Fig. 4Y). On the side opposite the stigma the channel is wider and extends across the

254 expanded central area (Fig. 4W, X, Y).

255 For morphometric description 40 valves were analyzed with LM, and 22 valves with SEM.

256

257 Type locality: Type: Rapa Nui, cave interior, Coordinates: $27^{\circ} 6^{\prime} 42^{\prime \prime S} 109^{\circ} 24^{\prime} 14^{\prime \prime} \mathrm{W}$, collected on 25830.04 .1988 by Prof. Georg Zizka from Senckenberg Institute.

259 Holotype: holotype designated here: slide SZCZ20608 (Fig. 4H) in the collection of Andrzej

260 Witkowski at the University of Szczecin.

261 Isotype: slide number 2020/11 in the Diatom Collection of the Institute of Agricultural Sciences, 262 Land Management and Environmental Protection at the University of Rzeszów.

263 Etymology: The name refers to the monolithic human figures on Rapa Nui, which are its most 264 characteristic landscape feature.

265

266 Luticola ectorii Levkov, Metzeltin \& Pavlov (Fig. 5).

267 Description: Valves rhombic to rhombic-elliptic, slightly asymmetric. Valve length 9.5-20.1 $\mu \mathrm{m}$, 268 width 5.2-7.0 $\mu \mathrm{m}$, with 22-24 striae in $10 \mu \mathrm{m}$. Apices broadly rounded. Central area bow-tie 269 shaped, bordered by single row of areolae (Fig. 5A-J). In the SEM, the valve is ornamented by 270 irregular depressions (Fig. 5L, M). The raphe is straight, with external proximal raphe ends 271 deflected away from the isolated stigma, which is located in the central area (Fig. 5K, M).

272 External distal raphe ends hooked to the side opposite the proximal ends and towards the stigma, 273 continuing onto the valve mantle (Fig. 5N). Transapical striae composed of 4-5 rounded areolae, 274 with a single row of areolae on valve mantle (Fig. $5 \mathrm{~N}$ ).

275 For morphometric description 15 valves were analyzed with LM, and 10 valves with SEM. 276

277 Taxonomic remarks: Specimens of the observed population had a smaller range of dimensions 278 than those presented in the monograph of the genus (Levkov et al., 2013). However they possess 
279 features typical of this species that allowed for its identification. These features include: the 280 middle part being weakly, asymmetrically swollen, broadly rounded apices, slightly

281

282

283

284

285

286

287

288

289

290

291

292

293

294

295

296

297

298

299

300

301

302

303

304

305

306

307

308

309 asymmetrical central area, stria and areola densities, and irregular depressions on vthe alve face.

\section{Ecology and associated diatom flora}

In the sample from which the newly described Luticola species originate, abundant populations of other terrestial taxa were observed (Fig. 6, 7). The most abundant of them were: Humidophila deceptioensis Kopalová, Zidarova \& Van de Vijver ( 58\%), Humidophila gallica (W.Smith) Lowe, Kociolek, Q.You, Q.Wang \& Stepanek ( 10\%), Humidophila cf. pantropica (LangeBertalot) Lowe, Kociolek, J.R.Johansen, Van de Vijver, Lange-Bertalot \& Kopalová ( 16\%) and Tryblionella debilis Arnott ex O'Meara ( 4\%). Additionally, various terrestrial species such as Angusticopula chilensis (Grunow) Houk, Klee \& H.Tanaka, Achnanthes tumescens A.R.Sherwood \& R.L.Lowe, Halamphora montana (Krasske) Levkov, Humidophila contenta (Grunow) Lowe, Kociolek, J.R.Johansen, Van de Vijver, Lange-Bertalot \& Kopalová, Humidophila sp., Geissleria ignota (Krasske) Lange-Bertalot \& Metzeltin and two unidentified Orthoseira species were common in the studied sample. In the studied sample, other taxa identified included: Cavinula sp., Denticula subtilis Grunow, Fallacia insociabilis (Krasske) D.G.Mann, Ferocia ninae Van de Vijver \& Houk, Halamphora normanii (Rabenhorst) Levkov, Mayamaea permitis (Hustedt) K.Bruder \& Medlin, Navicula veneta Kützing, Nitzschia inconspicua Grunow, Nitzschia cf. microcephala Grunow, Nitzschia vitrea G.Norman, Pinnularia borealis Ehrenberg, Rhopalodia brebissoni Krammer, Sellaphora atomoides (Grunow) Wetzel \& Van de Vijver, Sellaphora saugerresii (Desm.) Wetzel \& D.G.Mann and Staurosirella pinnata (Ehrenberg) D.M.Williams \& Round. These taxa appeared much less frequently, often in the form of single specimens and many of them had already been reported from the Rapa Nui Island by Cocquyt (1991).

\section{Discussion}

Recent studies show that numerous species of Luticola can be found across a diverse range of habitats worldwide. As shown in literature most Luticola taxa have a distinct preference for wet limno-terrestrial environments including: edges of streams, wet soils or living on bryophytes (Round et al., 1990; Kociolek et al., 2017). 
310 Although a large number of Luticola species have been described as new to science in recent

311 years, it was impossible to identify 3 of the 4 Rapa Nui Luticola populations we studied based on

312 this currently available literature. Some previously-described Luticola species do show

313 similarities with the newly described taxa. Included in this group are e.g. L. spinifera (W.Bock)

314 L.Denys \& W.H.De Smet, L. frequentissima Levkov, Metzeltin \& A.Pavlov, L. puchalskiana

315 Kochman-Kedziora, Zidarova, T.Noga, Olech \& B.Van de Vijver and Luticola andina Levkov,

316 Metzeltin \& A.Pavlov (Levkov et. al., 2013, refs). However, none of the above species

317 conformed with our new species in terms of size dimensions and/or ultrastructural

318 characteristics.

319 Luticola georgzizkae sp. nov. possesses a combination of features unique within Luticola. So far 320 only two of the established species in Luticola possess marginal spines - L. spinifera and $L$.

321 lagerheimii, but the shapes of their valves and their dimensions (Levkov et al., 2013) easily

322 separate them from L. georgzizkae. In addition, the two aforementioned taxa are characterized by 323 a single morphology, whereas the newly described species has two morphotypes (spine-bearing 324 and spineless forms). Moreover, in the case of L. spinifera and L. lagerheimii, the spines are 325 positioned only on the edge of the valve and support formation of ribbon-like colonies. In the 326 case of L. georgzizkae sp. nov. conjoined valves were not observed and the spines are also 327 present directly on the surface of the valve. Denys and Smet (1996) in studying Luticola spinifera suggested that spines present were capable of strong adhesion to the substratum. Colony formation might offer some compensation for the potential disadvantages of having small-sized frustules, such as the possibility of movement by wind. Colony formation also significantly reduces the area from which water may be quickly lost. Unfortunately growing in colonies limits the ability of individual cells to move, reducing the chances of finding more suitable environmental conditions in a constantly-changing terrestrial environment (Bock, 1963; Denys \& Smet, 1996). It seems that Luticola georgzizkae sp. nov. was able to combine both strategies, by creating forms with and without spines. In this study we were unable to observe colony formation, but this may be due to the low number of observations, or disconnection due to the sample cleaning process.

338 A similar phenomena has also been observed in Humidophila gallica (W.Smith) Lowe,

339 Kociolek, Q.You, Q.Wang \& Stepanek (syn. Diadesmis gallica W.Smith). Mature valves of this species presented two morphotypes: one with a raphe system and no marginal spines, the other 
341 with marginal spines and without a raphe system (Cox, 2006). This same diatom species reduces

342 the raphe length, following the development of colonies (Kociolek \& Rhode 1998). Also, in our

343 study the spiny morphotype had a shorter raphe slit. It has also been suggested that the sealed

344 raphe slit of an attached cell might minimize the risk of parasitism or infection (Cox, 2006).

345 Which may mean that diatoms, at least those from terrestrial and aerophytic habitats, protect the

346 cell content from external environment by reducing the raphe slit length or by sealing it off

347 completely.

348 The second described species, Luticola rapanuiensis sp. nov. is most similar to L. frequentissima

349 Levkov, Metzeltin \& Pavlov. Both species possess thread-like depressions on the central raphe

350 endings, but in L. frequentissima they are not conjoined with areolae from striae bordering the

351 central area. Both taxa have similar size dimensions but valves of L. frequentissima are usually

352 larger (5.2-15.9 $\mu \mathrm{m}$ long and 4.3-7.6 $\mu \mathrm{m}$ wide in L. rapanuiensis sp. nov. vs. 6.2-27.0 $\mu \mathrm{m}$ long

353 and 4.0-9.0 $\mu \mathrm{m}$ wide in L. frequentissima) (Levkov et al., 2013; Noga et al., 2017). Additionally,

354 L. frequentissima has denser striae with higher areola number in an individual stria. Luticola

355 frequentissima has 18-27 striae in $10 \mu \mathrm{m}$ (Noga et al., 2017) composed of 4-6 areolae while $L$.

356 rapanuiensis sp. nov. has 16-19 striae in $10 \mu \mathrm{m}$ composed usually of 2-3 areola. Moreover, $L$.

357 rapanuiensis $\mathrm{sp}$. nov. has siliceous ridges over valve face/mantle conjunction which has not been

358 observed in L. frequentissima (Levkov et al., 2013).

359 Luticola moaiorum sp. nov. belongs to a group of small species that have elliptic-lanceolate

360 valve outlines. From this group the most similar taxa are L. ipevii Van de Vijver \& Levkov, $L$.

361 puchalskiana Kochman-Kedziora, Zidarova, Noga, Olech \& Van de Vijver and L. andina

362 Levkov, Metzeltin \& Pavlov. The newly described species can be easily distinguished from $L$.

363 ipevi based on denser striae (18-24, vs. 14-18 in $10 \mu \mathrm{m})$ and mainly shorter and narrower

364 valves. Another important characteristic is that L. ipevii has distal raphe fissures that continue

365 onto the valve mantle (Levkov et al., 2013). Also, large valves of L. ipevii show slightly

366 separated, broadly rounded apices while L. moaiorum sp. nov. has a regularly elliptic-lanceolate

367 valve shape across the size range. The basic feature that distinguishes Luticola moaiorum $\mathrm{sp}$.

368 nov. from L. puchalskiana is shape of central and distal raphe endings, which are simply bent to

369 site opposite to stigma in first species, while in case of L. puchalskiana both raphe endings are

370 hooked toward stigma-bearing side. The shape of the valves of both species is also different. In

371 L. moaiorum sp. nov. the valves are elliptic-lanceolate while in L. puchalskiana they are 
372 rhombic-lanceolate (Kochman-Kędziora et al., 2020). Luticola andina differs from L. moaiorum

373 sp. nov. by the shape of the central area which is elliptical to rectangular, not bow-tie shaped,

374 and by a distinct axial area which is narrow in case of L. moaiorum sp. nov. Also newly

375 described species show more radiate striae than L. andina (Levkov et al., 2013).

376 It is interesting to note that while there are 4 species present in the sample from Rapa Nui, they

377 are quite different from one another morphologically. For example, L. georgzizkae, L.

378 rapanuiensis and L. moaiorum have external central and distal raphe ends that are curved in the 379 same direction, though in the former the raphe ends are curved towards the stigma while in the 380 latter two species they are directed away from the stigma. In L. ectorii the central and distal 381 raphe ends are deflected in opposite directions. In three of the species, the internal structure of

382 the stigma is similar to most Luticola species, a circular and lipped structure having an indistinct 383 opening (e.g. Levkov et al., 2013), while in L. rapanuiensis the internal stigma structure is 384 simpler, with an opening in the center of the stigma. About the internal marginal channels, in $L$. 385 georgzizkae they are prominent and tube-like, in L. rapanuiensis are barely resolvable, and in L. 386 moaiorum there is a prominent extension of the channel across one side of the central area. This 387 diversity of morphologies in the few species present on Rapa Nui might suggest these species 388 arrived from different dispersal events, and are not a radiation from a single immigrant.

389 Diatom studies from Rapa Nui, though very few, do present some observations on Luticola 390 species in the crater lakes and crater lake sediments. Firstly Cocquyt (1991) reported an 391 occurrence of Luticola mutica (as Navicula mutica) in the crater lakes and this observation is 392 documented with a line drawing. Subsequently, Dumont et al., (1998) published results of 393 diatomological analyses of a sediment core from the crater lake and provided a taxa list of 394 diatoms identified. This list includes mostly cosmopolitan taxa and, amongst them, three species 395 of Luticola identified (as Navicula s.1.). These species included Navicula goeppertiana (Bleisch) 396 H. L. Smith (=Luticola goeppertiana (Bleisch) D.G.Mann), Navicula goeppertiana var. monita 397 (Hustedt) Lange-Bertalot (=Navicula monita Hustedt; Luticola monita (Hustedt) D.G.Mann) and 398 Navicula mutica (=Luticola mutica). With the above taxa the number of Luticola taxa in Rapa 399 Nui terrestrial and limnic waters increases to seven, three of which are new to science. It is worth 400 comparing these figures with the closest continental mass which is the coast of South America 401 and the Andes Mountains. Rumrich et al. (2000) in their monograph identified eleven Luticola 402 species in samples representing one of the Earth's longest mountain ranges taken from the Feuer 
403 Land up to Panama. Among the reported Luticola species only two had been described as new to 404 science and an additional seven were identified to the genus level only implying, they may 405 potentially also be species new to science. Furthermore, of numerous cosmopolitan Luticola 406 species, only L. goeppertiana was observed in the Andes. Also, when we analyze the 407 Subantarctic Islands the figures in terms of Luticola species diversity are similar even though, as 408 a rule, more extensive sampling has been done. This is fairly different from the case of Rapa Nui, 409 where in one sample we have been able (thus far) to identify and describe three species new to 410 science.

411 The identification of Luticola (Navicula) mutica from limnic waters of Rapa Nui may be 412 perceived as problematic, since this taxon is considered a mud-dwelling, brackish water species 413 (Levkov et al., 2013). However, an argument in support of L. mutica occurring in freshwaters of 414 Rapa Nui comes from species composition of the surface waters and of the core from the crater 415 lake. In the species lists from both sites diatom taxa which are considered brackish water forms 416 are included. Examples in this group are: Cyclotella meneghiniana, Navicula cf. phyllepta, 417 Nitzschia cf. vidovichii or N. vitrea. We interpret this as an indication of strong winds which 418 transfer an aerosol and sea salts from the sea coastal zone to the freshwater habitats.

\section{Conclusions}

421 Taking into consideration all described Luticola species, it seems that three new species 422 described in this paper have a unique set of characters allowing their correct identification. So 423 far, Luticola georgzizkae sp. nov., Luticola rapanuiensis sp. nov., and Luticola moaiorum sp. 424 nov. are known only from Rapa Nui Island. Taking into account the fact that there is a high 425 degree of endemism within Luticola (Kociolek et al., 2017), as well as a high degree of island 426 isolation, it is very possible that the endemic species described from Rapa Nui do not exist 427 elsewhere.

\section{Acknowledgements}

432 The authors express their gratitude to Professor Dr. Georg Zizka for providing the samples from 433 Rapa Nui collected during his work on flowering plants. 
435

\section{References}

437 Aldén B. 1990. Wild and introduced plants on Easter Island: A report on some species noted in 438 February 1988. In Esen-Baur, H. M. (ed.), State and perspectives of scientific research in Easter 439 Island culture. Courier Forschungsinstitut Senckenberg, Frankfurt, Germany, 1990, 209-216.

440

441

442

443

444

445

446

447

448

449

450

451

452

453

454

455

456

457

458

459

460

461

462

463

464

465

Bąk M, Kociolek JP, Lange-Bertalot H, Łopato D, Witkowski A, Zgłobicka I, Seddon AWR 2017. Novel diatom species (Bacillariophyta) from the freshwater discharge site of Laguna Diablas (Island Isabela = Albemarle) from the Galapagos. Phytotaxa 311(3): 201-224. https://doi.org/10.11646/phytotaxa.311.3.1

Bąk M, Kryk A, Peszek Ł, Kociolek JP, Bemiasa J, Bemanaja E. 2019. New and interesting Luticola species (Bacillariophyta) from the mangroves of Nosy Be Island, NW Madagascar". Oceanological and Hydrobiological Studies 48(1): 13-22. https://doi.org/10.1515/ohs-2019-0002

Bock W. 1963. Diatomeen extrem trockener Standorte. Nova Hedwigia 5:199-254.

Bustos S., Morales M.R., Maidana N.I. 2017. Diversidad del género Luticola (Bacillariophyceae) en sedimentos holocenicos de la Puna Jujeña, Argentina. Bol. Soc. Argent. Bot. 52 (1): 13-26.

Charola AE. 1994. Easter Island The Heritage and its Conservation. World Monuments Fund, New York.

Chattová B, Lebouvier M, De Haan M, Van De Vijver B. 2017. The genus Luticola

(Bacillariophyta) on Ile Amsterdam and Ile Saint-Paul (Southern Indian Ocean) with the description of two new species. European Journal of Taxonomy 387:1-17. https://doi.org/10.5852/ejt.2017.387.

Cholnoky BJ. 1954. Diatomeen und einige andere Algen aus dem “de Hoek"—Reservat in Nordtransvaal. Bot Notiser 3:269-296

Peer) reviewing PDF | (2020:11:55610:1:1:NEW 16 Feb 2021) 
466 Ciszewski A, Ryn ZJ., Szelerewicz M. 2009. The Caves of Easter Island: Underground World of 467 Rapa Nui. Pracownia Kreatywna Bezliku, Kraków.

468

469 Da Silva-Lehmkuhl A.M., Ludwig T.A.V., Tremarin P.I., De Campos Bicudo D. 2019. On 470 Luticola Mann (Bacillariophyceae) in southeastern Brazil: taxonomy, ecology and description of 471 two new species. Phytotaxa 402(4): 165-186. https://doi.org/10.11646/phytotaxa.402.4.1

472

473 Cocquyt, C. 1991. Diatoms from Easter Island. Biologisch Jaarboek Dodonuea 59:109-124

474

475

Cox EJ. 2006. Raphe loss and spine formation in Diadesmis gallica (Bacillariophyta) - an $477 \quad 176$.

478

Denys L, De Smet W.H. 1996. Observations on the subaerial diatom Navicula spinifer Bock, and its transfer to Luticola Mann. Cryptogamie Algologie 17:77-93.

481

482

Diamond J. 2005. Collapse: how societies choose to fail or succeed. Viking Books, New York

483

484

Dubois A, Lenne P, Nahoe E, Rauch M. 2013. Plantas de Rapa Nui. Guía ilustrada de la flora de 485 interés ecológico y patrimonial. Umangamo te Natura, CONAF, ONF Int., Santiago, 132 pp.

Dumont, H.J., Cocquyt, C., Fontugne, M., Arnold, M., Reyss, J-L., Bloemendal, J., Oldfield, F., 488 Steenbergen, C.L.M., Korthals, H.J., Zeeb, B.A. 1998. The end of moai quarrying and its effect 489 on Lake Rano Raraku, Easter Island. Journal of_Paleolimnology 20: 409-422.

490 https://doi.org/10.1023/A:1008012720960

491

492

493

494

495

496

497

498

Etienne M, Faúndez L. Gramíneas de Isla de Pascua. Facultad de Ciencias Agrarias, Veterinarias y Forestales, Universidad de Chile, Boletín Técnico 1983; 12: 1-55.

Finot VL, Marticorena C, Marticorena A, Rojas G, Barrera JA. 2015. Grasses (Poaceae) of Easter Island - Native and Introduced Species Diversity. Biodiversity in Ecosystems - Linking Structure and Function, Yueh-Hsin Lo, Juan A. Blanco and Shovonlal Roy, IntechOpen, DOI: 10.5772/59154. Available from: https://www.intechopen.com/books/biodiversity-in-ecosystems- 
499 linking-structure-and-function/grasses-poaceae-of-easter-island-native-and-introduced-species500 diversity

501

502 Giffen MH. 1966. Contributions to the diatom flora of Southern Africa. II. Diatoms from the 503 Hog's Back región of the Amatola Mountains, Eastern Cape Province. Beihefte zur Nova 504 Hedwigia 21:123-160.

505

506 Glushchenko A.M, Kulikovskiy MS. 2015 The genus Luticola (Bacillariophyceae) in water 507 ecosystems of South-Eastern. Botanicheskiy Zhurnal 100:799-804.

508

509

Gluschenko AM, Kulikovskyi MS, Kociolek JP. 2018. New and interesting species from genus 510 Luticola (Bacillariophyceae) in waterbodies of Southeastern Asia. Nova Hedwigia Beiheft 511 146:157-173. https://doi.org/10.1127/1438-9134/2017/157

512

513 Guiry M.D in Guiry M.D. \& Guiry G.M. 2020. AlgaeBase. World-wide electronic publication, 514 National University of Ireland, Galway. http://www.algaebase.org; searched on 16 September 5152020.

\section{6}

517 Hamilton S. 2013. Rapa Nui (Easter Island)'s Stone Worlds. Archaeology International, 16, 518 519

520 pp.96-109. http://doi.org/10.5334/ai.1613

Heiden H, Kolbe RW. 1928. Die marinen Diatomeen der Deutschen Südpolar-Expedition 1901521 1903. Deutsche Südpolar Expedition 8 (Botany):447-715.

522

523 Hustedt F. 1962. Die Kieselalgen Deutschlands, Österreichs und der Schweiz unter

524 Berücksichtigung der übrigen Länder Europas sowie der angrenzenden Meeresgebiete. Bd. VII:

525 Teil 3: Lieferung 2. In: Rabenhorst's Kryptogamen Flora von Deutschland, Österreich und der 526 Schweiz. (Anon. Eds), Leipzig: Akademische Verlagsgesellschaft m.b.h.161-348.

527

528 Hustedt F. 1937-1939. Systematische und ökologische Untersuchungen über die Diatomeen529 Flora von Java, Bali und Sumatra: nach dem Material der Deutschen Limnologischen Sunda530 Expedition. Archiv für Hydrobiologie, Supplement 15-16. 
531

532 Hunt TL. 2007. Rethinking Easter Island's ecological catastrophe. Journal of Archaeological 533 Science 34, 485-502. https://doi.org/10.1016/j.jas.2006.10.003

534

535 Kopalová K, Nedbalová L, De Haan M, Van de Vijver B. 2011. Description of five new species 536 of the diatom genus Luticola (Bacillariophyta, Diadesmidaceae) found in lakes of James Ross

537 Island (Maritime Antarctic Region). Phytotaxa 27:44-60.

538 https://doi.org/10.11646/phytotaxa.27.1.5

539

540 Kochman-Kędziora N, Zidarova R, Noga T, Olech M, Van de Vijver B. 2020. Luticola

541 puchalskiana, a new small terrestrial Luticola species (Bacillariophyceae) from the Maritime

542 Antarctic Region. Phytotaxa 450(1):85-94. https://doi.org/10.11646/phytotaxa.450.1.6

543

544 Kociolek JP, Kopalová K, Hamsher SE. Kohler TJ, Van de Vijver B, Convey P, McKnight DM.

545 2017. Freshwater diatom biogeography and the genus Luticola: an extreme case of endemism in 546 Antarctica. Polar Biology 40, 1185-1196. https://doi.org/10.1007/s00300-017-2090-7

547

548 Kociolek JP, Rhode K. 1988. Raphe vestiges in Asterionella species from Madagascar: Evidence 549 for a polyphyletic origin of the araphid diatoms ? Cryptogamie Algologie 19:57-74

550

551 Krammer K., Lange-Bertalot H. 1988. Süßwasserflora von Mitteleuropa. Bacillariophyceae 1.

552 Teil, Naviculaceae. - In: Ettl, H., Gerloff, J., Heynig, H. \& Mollenhauer, D. (eds):

553 Süßwasserflora von Mitteleuropa. 2 (2). G. Fischer, Stuttgart \& New York.

554

555

Lange-Bertalot, H. 1977. Eine Revision zur Taxonomie der Nitzschiae Lanceolatae Grunow.

556 Nova Hedwigia 28:253-307

557

558 Lange-Bertalot H, Hofmann G, Werum M, Cantonati M. 2017. Freshwater Benthic Diatoms of

559 Central Europe: Over 800 Common Species Used in Ecological Assessment; English edition

560 with updated taxonomy and added species; Cantonati, M., Kelly, M.G., Lange-Bertalot, H., Eds.;

561 Koeltz Botanical Books: Schmitten, Germany. 
562

563 Levkov Z, Metzeltin D, Pavlov A. 2013. Luticola and Luticolopsis. [In:] H. Lange-Bertalot (Ed.), 564 Diatoms of Europe 7, Diatoms of the European inland waters and comparable habitats. Koeltz 565 Scientific Books, Köningstein - Germany.

566

567 Lokhande V, Radhakrishnan C, Kociolek JP, Lowe R, Karthick B. 2020. The diatom genus 568 Luticola D.G. Mann (Bacillariophyceae) in the Western Ghats of India and its biogeography.

569 European Journal of Phycology https://doi.org/10.1080/09670262.2020.1783460

570

571 Mann D, Edwards J, Chase J, Beck W, Reanier R, Mass M., Finney B, Loret J. 2008. Drought, 572 vegetation change, and human history on Rapa Nui (Isla de Pascua, Easter Island). Quaternary 573 Research 69:16-28. https://doi.org/10.1016/j.yqres.2007.10.009

574

575 Metzeltin D, Lange-Bertalot H. 2005. Diatoms of Uruguay. Compared with other taxa from 576 South America and elsewhere. In: Lange-Bertalot, H. (Ed.). Iconographia Diatomologica 15: 1577736.

578

579 Metzeltin D, Lange-Bertalot H. 1998. Tropical diatoms of South America I. About 700 580 predominantly rarely known or new taxa representative of the neotropical flora. In: Lange581 Bertalot, H. (Ed.). Iconographia Diatomologica 5:1-695.

582

583 Navarro JM. 2002. Florella pascuensis sp. nov., a new marine diatom species from Easter Island 584 (Isla de Pascua), Chile. Diatom research 17(2): 283-289.

585 https://doi.org/10.1080/0269249X.2002.9705548

586

587 Noga T, Stanek-Tarkowska J, Kochman-Kędziora N, Rybak M, Peszek Ł, Poradowska A. 2017.

588 Luticola frequentissima Levkov, Metzeltin \& Pavlov -morphological and ecological 589 characteristics of a population from Southern Poland. Oceanological and Hydrobiological 590 Studies 46(2): 237-243. https://doi.org/10.1515/ohs-2017-0024 
592 Patrick RM, Reimer C.W. 1966. The Diatoms of the United States exclusive of Alaska and 593 Hawaii, V. 1 Monographs of the Academy of Natural Sciences of Philadelphia 13.

594

595 Quilliam L, Cox R, Campbell P, Wright M. 2014. Coastal climate change impacts for Easter 596 Island in 2100. Rapa Nui Journal 28(1): 60-67.

597

598

599

Round FE, Crawford RM, Mann DG. 1990. The Diatoms. Biology and Morphology of the Genera; Cambridge University Press: Cambridge, UK.

600

601

Rumrich U, Lange-Bertalot H, Rumrich M. 2000. Diatomeen der Anden. Von Venezuela bis

602

Patagonien/Feuerland. [W:] H. Lange-Bertalot (red.), Iconographia Diatomologica 9, Annotated

603 Diatom Micrographs. A.R.G. Gantner Verlag K.G., Ruggell, 649 ss.

604

605

Rull V, Cañellas-Bolta N, Sáez A., Giralt S, Pla S, Margalef O. 2010. Paleoecology of Easter

606 Island: Evidence and uncertainties. Earth Sciences Reviews 99:50-60.

607 https://doi.org/10.1016/j.earscirev.2010.02.003

608

609

Simonato J, Kociolek JP, Sala SE, Díaz YP, Núñez-Avellaneda M. 2020. Three new Luticola

610 species from the Andean-Amazonian transition in Colombia: taxonomy, morphology and

611 preliminary considerations of the biogeography of the genus. Diatom Research, 2020

612 https://doi.org/10.1080/0269249X.2020.1813205

613

614 Straube A., Tremarin P.Z., Ludwig T.A.V. 2017. Species of Luticola D.G. Mann

615 (Bacillariophyceae) in the Atlantic Forest rivers from southern Brazil. Diatom Research 32(4):

616 417-437. https://doi.org/10.1080/0269249X.2017.1389771

617

618 Towns DR, Atkinson IAE, Daugherty CH. 2006. Have the harmful effects of introduced rats

619 been exaggerated? Biological Invasions 8: 863-891. https://doi.org/10.1007/s10530-005-0421-z 620

621 Van de Vijver B, Frenot Y, Beyens L. 2002. Freshwater diatoms from Ile de la Possession 622 (Crozet Archipelago, Subantarctica) Bibliotheca Diatomologica 46:1-412 
623

624 Zizka G. 1991. Flowering plants of Easter Island. Palmarum Hortus Francofurt am Main, 625 Germany 3:1-108

626 
Figure 1

Study area. (A) Lcation of Rapa Nui island (arrow). (B) Location of the studied cave.

(A) Lcation of Rapa Nui island (arrow). (B) Location of the studied cave.

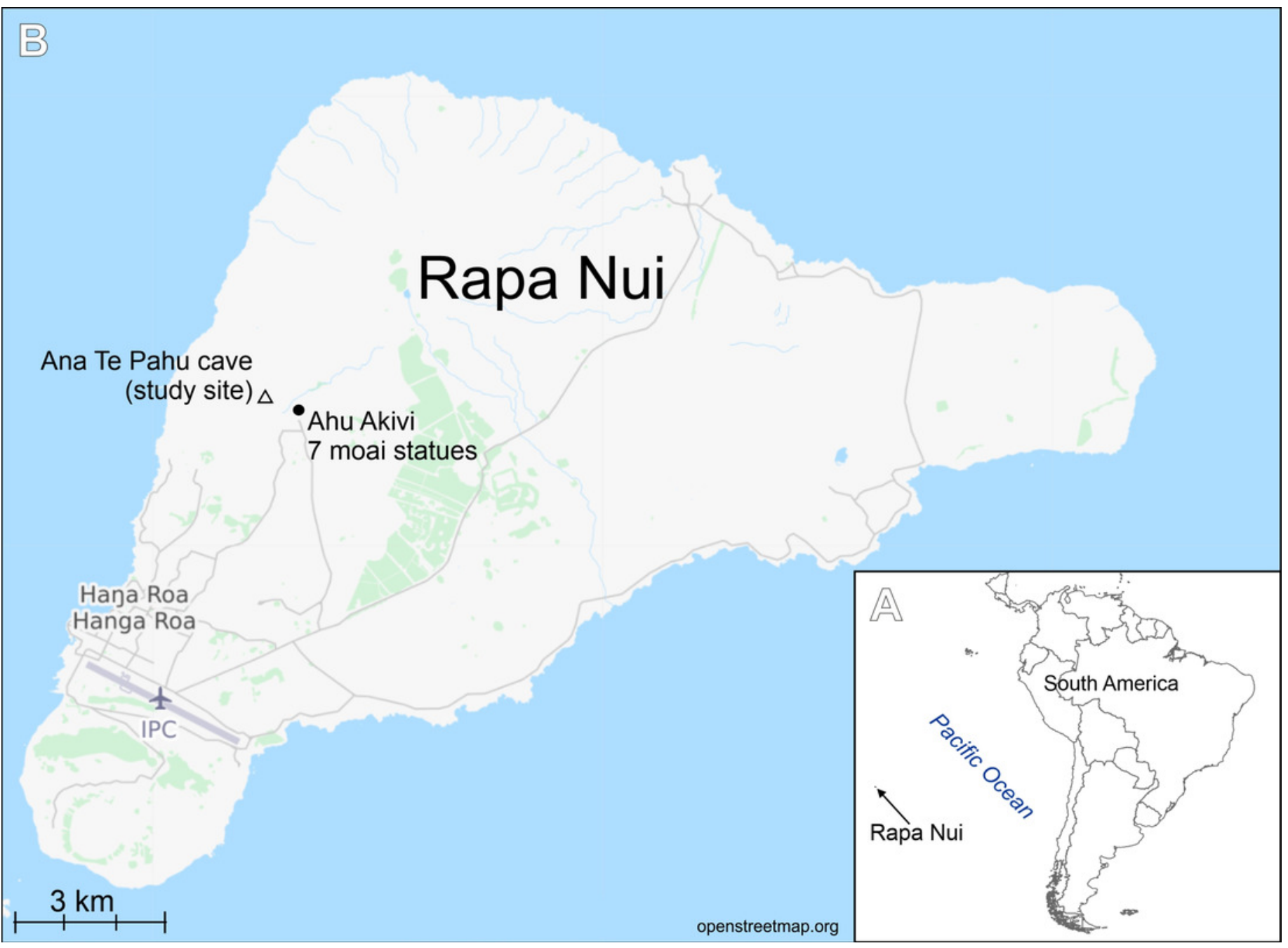




\section{Figure 2}

Luticola georgzizkae sp. nov.

(A-N) LM images showing diminution series. (A, B, E, G) Valve morphotypes with clearly visible marginal spines (arrows). (D) holotype specimen. (H) isotype specimen. (O-AC) SEM images. (O-R) External view of the valve face with spines (arrow in Fig. R). (S) External valve view of specimen without spines. (T) Detailed view of external proximal raphe endings associated with stigma (arrow). (U, V) Detailed view of external distal raphe endings terminating below apices (arrow in Fig. U). (W, X) Internal view of the whole valves. (Y) Internal view of central area and distal raphe endings terminating below the valve apices (arrow). (Z) Internal view of proximal raphe endings, note marginal channel (arrow), and stigma (black arrow). (AA) Girdle view of the whole frustule. (AB) Detailed valve mantle in girdle position with clearly visible marginal spines (arrow). (AC) Detached girdle band. Scale bars: (A-N, W) $10 \mu \mathrm{m},(\mathrm{O}-\mathrm{S}, \mathrm{X}, \mathrm{Y}, \mathrm{AA}-\mathrm{AC}) 5 \mu \mathrm{m},(\mathrm{T}-\mathrm{V}, \mathrm{Z}) 3 \mu \mathrm{m}$. 

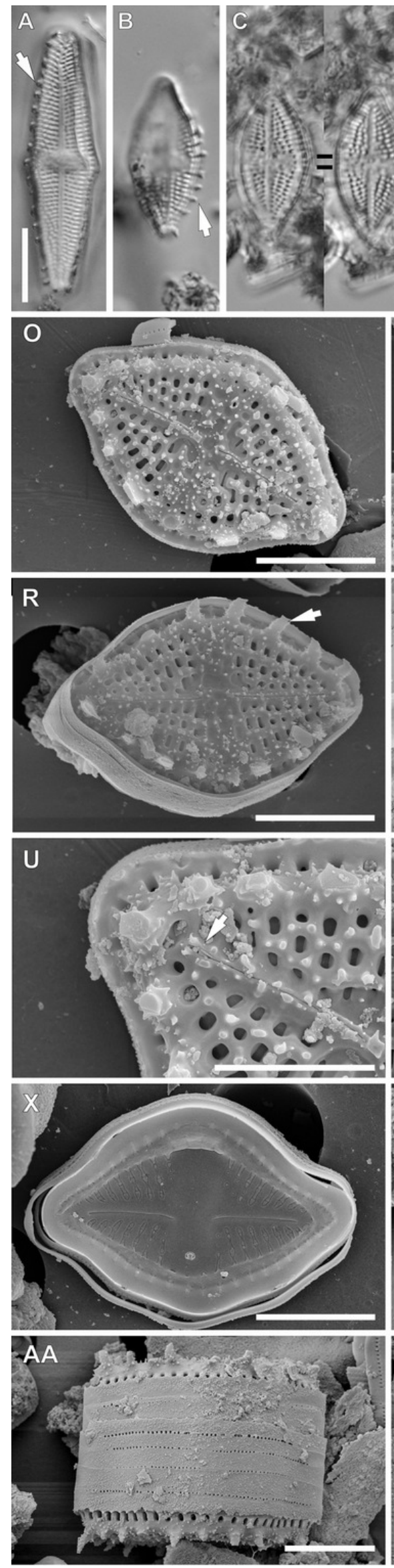
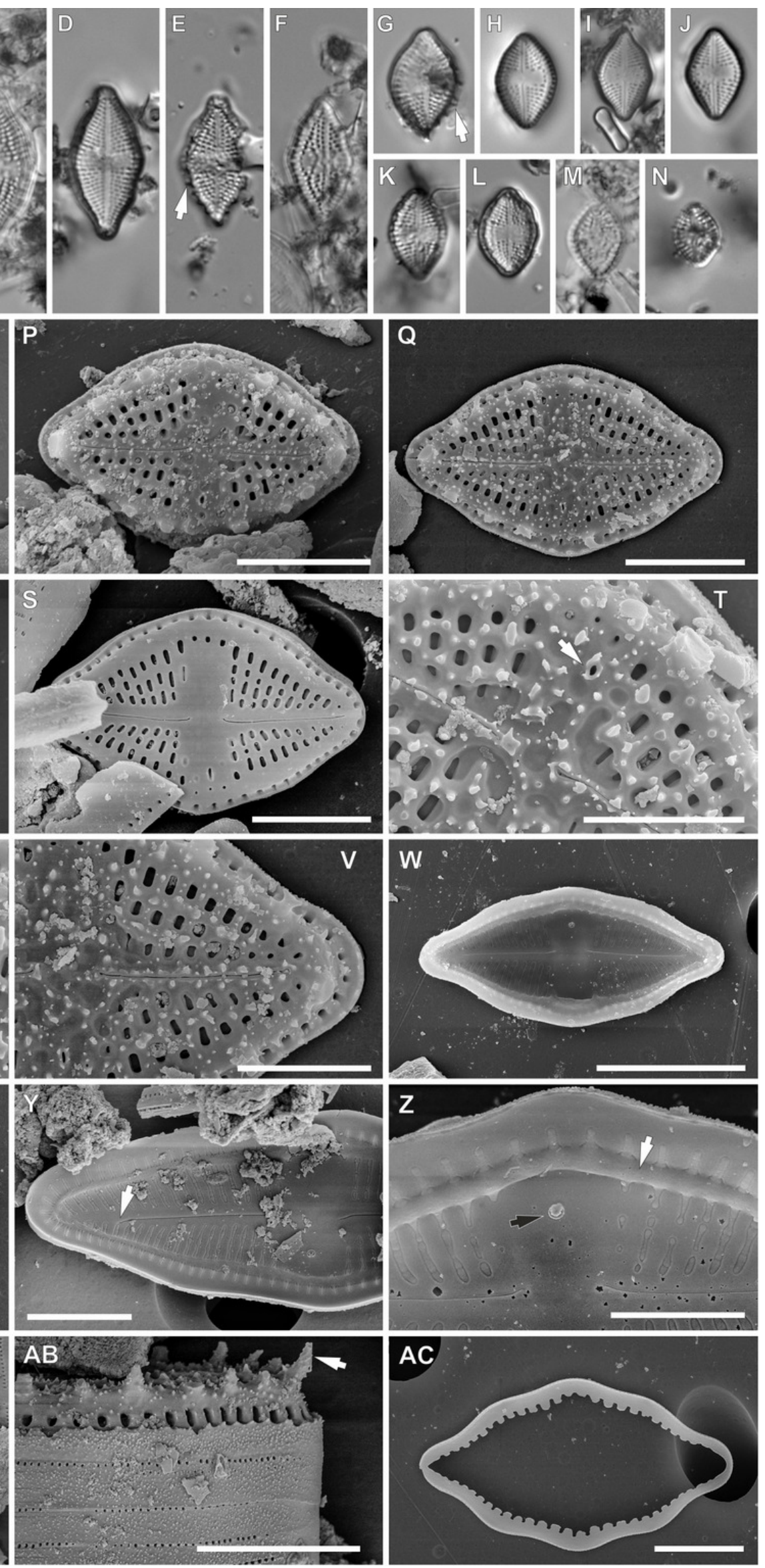


\section{Figure 3}

Luticola rapanuiensis sp. nov.

(A-P) LM images showing size diminution series. (F) Isotype specimen. (H) Holotype specimen. (Q-AB) SEM images. (Q-V) External views of the entire valve. (T) External valve view, with clearly visible ghost areola (arrow). (U) External valve view of central raphe endings with elongated shape and grooves (arrow). (W) Close up of the specimen illustrated in Fig. T, with large ghost areola (arrow), stigma (black arrow), proximal and distal raphe endings slightly bent to the same side. $(\mathrm{X})$ Close up of central part of the valve, with proximal raphe endings evident. (Y) Close up of the valve apex with siliceous ridges on valve face/mantle conjunction (arrow) clearly evident. (Z) Valve in a girdle view. (AA) Internal view of whole valve. ( $A B$ ) Internal view of valve illustrating stigma (arrow) and central raphe endings. Scale bar: (A-P) $10 \mu \mathrm{m},(\mathrm{Q}-\mathrm{U}, \mathrm{X}, \mathrm{Z}, \mathrm{AA}) 5 \mu \mathrm{m},(\mathrm{V}, \mathrm{Y}) 4 \mu \mathrm{m}$, (W) $3 \mu \mathrm{m}$, (AB) $1 \mu \mathrm{m}$. 

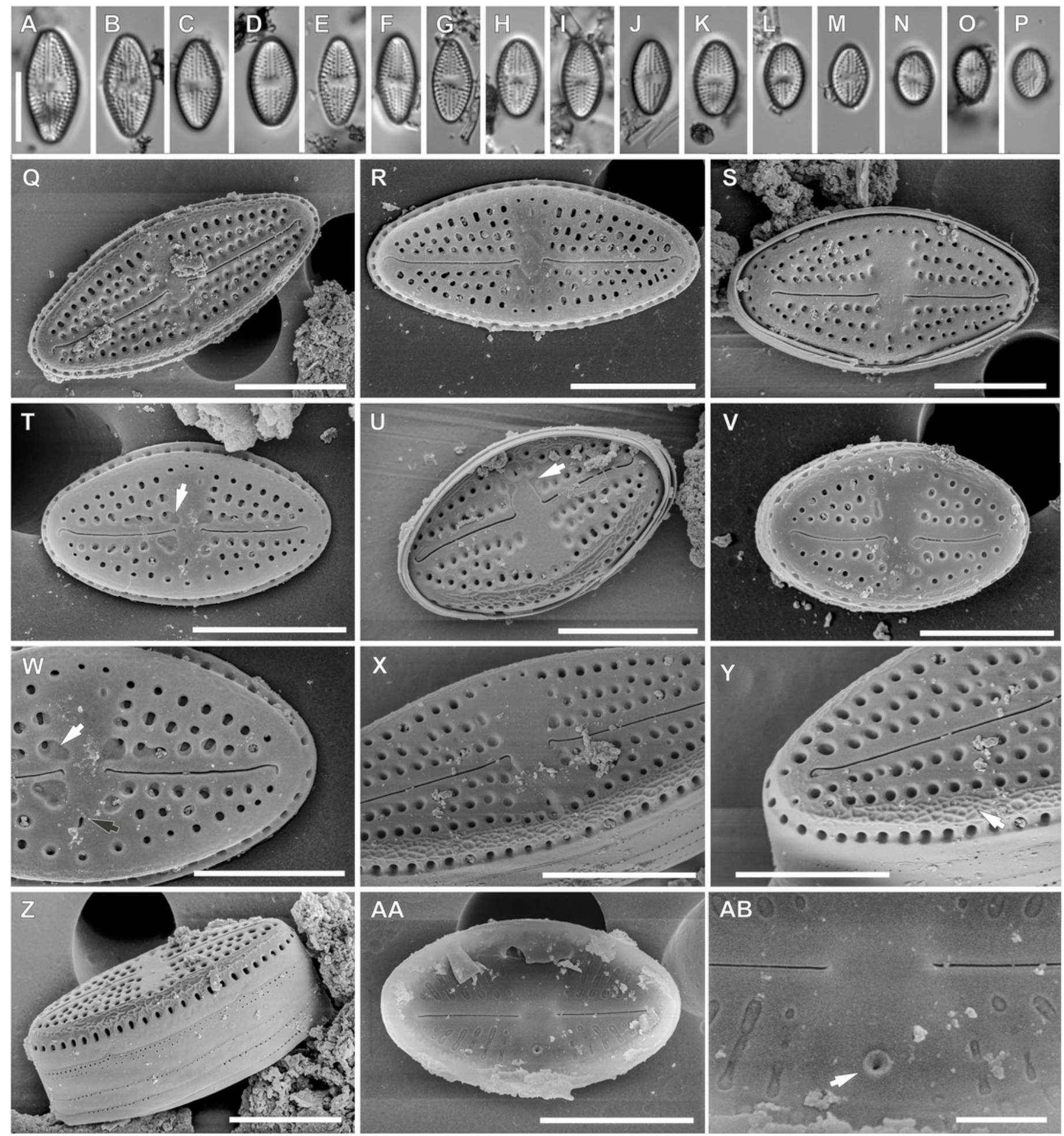

AB

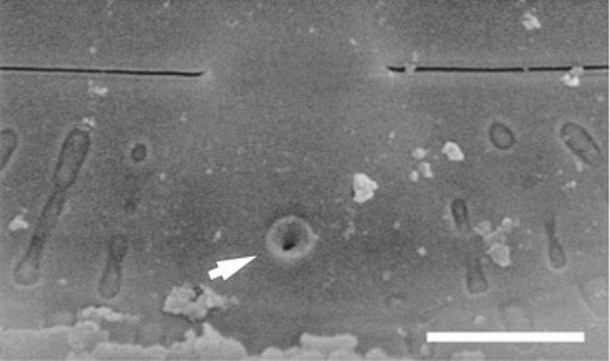




\section{Figure 4}

Luticola moaiorum sp. nov.

(A-N) LM images showing size diminution series. (H) Holotype specimen. (I) Isotype specimen. (O-Z) SEM images. (O-T) External valve views, note stigma position (arrow in Fig.

T). (U) Close up of the specimen illustrated in Fig. P, illustrating the central area, with stigma covered by a mineral particle (arrow) and proximal raphe endings deflected to one side. (V) Close up of the valve apex with distal raphe ending and siliceous ridges on valve face/mantle conjunction evident (arrow). (W, X) Internal view of the entire valve. (Y) Close up of the specimen illustrated in Fig. $X$, showing the central area valve apex; note the marginal channel (arrow). (Z) Close up of the specimen illustrated in Fig. $X$, showing central area and stigma (arrow). Scale bar: (A-N, P) $10 \mu \mathrm{m},(\mathrm{O}, \mathrm{Q}-\mathrm{X}) 5 \mu \mathrm{m},(\mathrm{Y}) 4 \mu \mathrm{m},(\mathrm{Z}) 1 \mu \mathrm{m}$. 

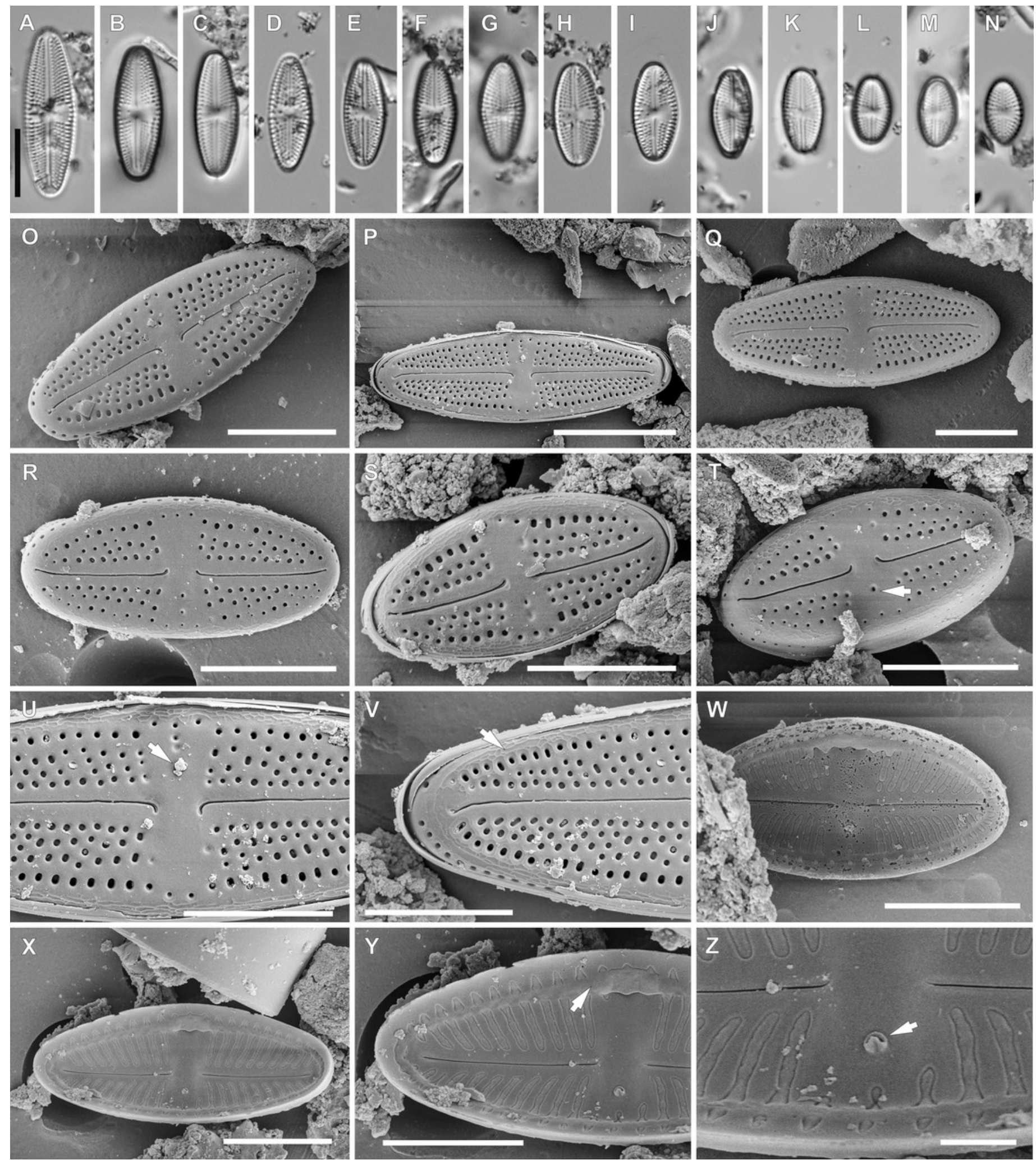


\section{Figure 5}

Luticola ectorii Levkov, Metzeltin \& A.Pavlov.

(A-J) LM images showing size diminution series. (K-N) SEM images of the valve illustrating the valve exterior, note the stigma in Fig. $\mathrm{K}$ (arrow) and proximal (black arrow) and distal raphe endings (white arrow) bent in one side. Scale bars: (A-J) $10 \mu \mathrm{m},(\mathrm{K}-\mathrm{M}) 5 \mu \mathrm{m},(\mathrm{N}) 4 \mu \mathrm{m}$.
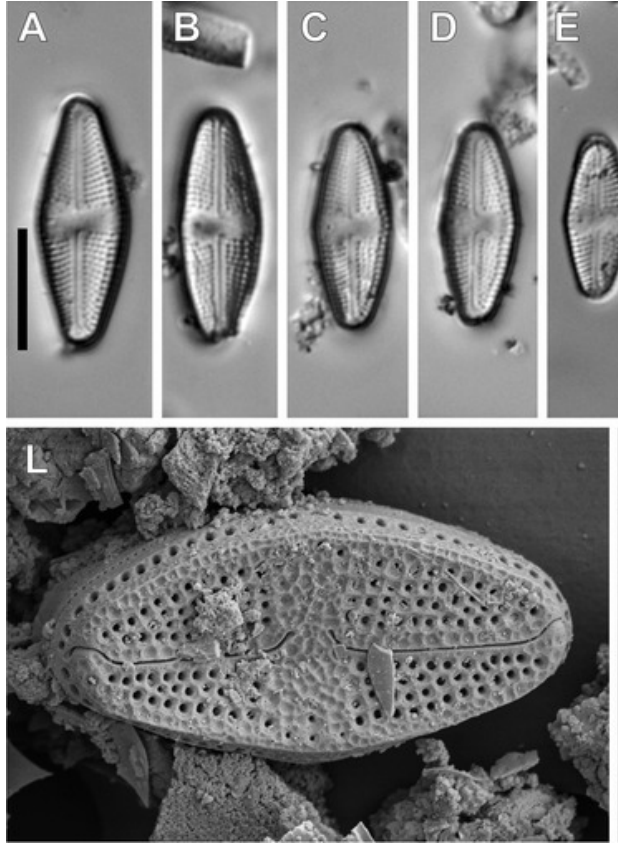
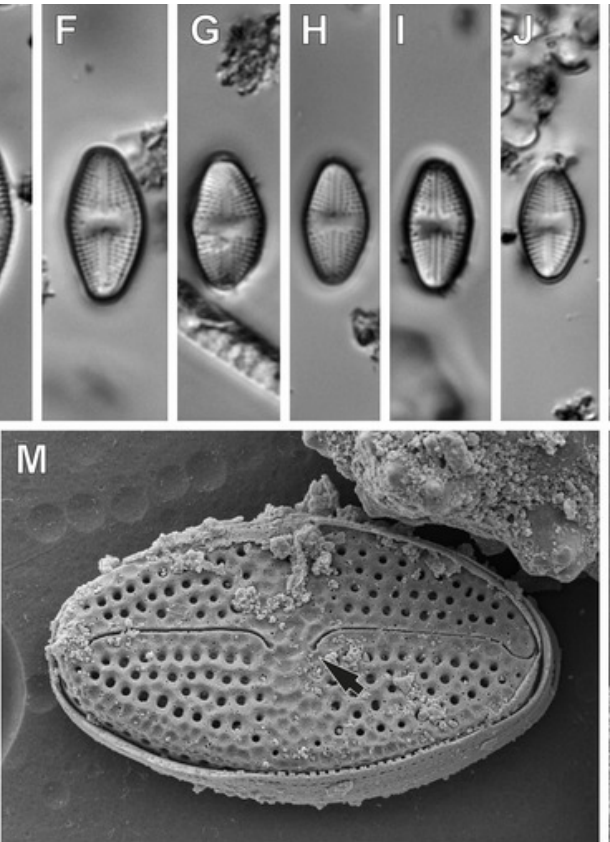

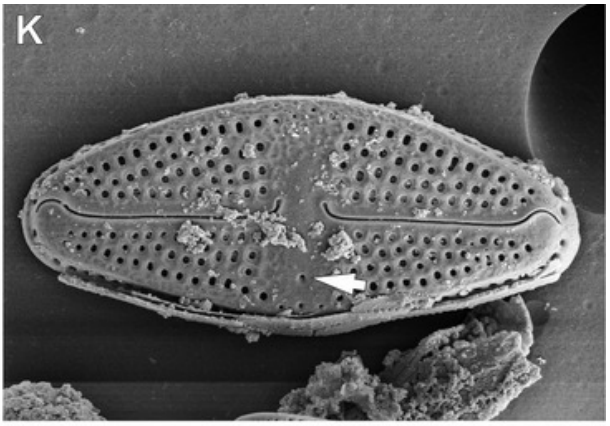

N

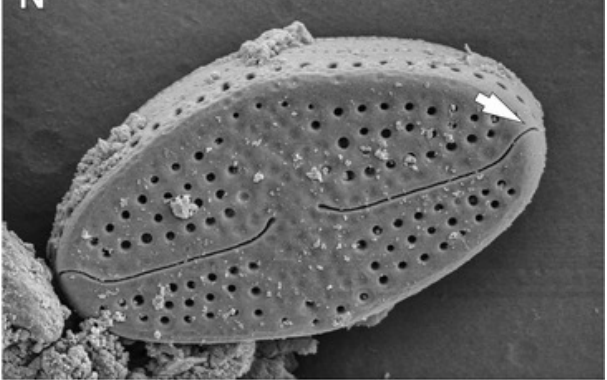




\section{Figure 6}

Associeted diatom flora (LM images).

(A-D) Angusticopula chilensis (Grunow) Houk, Klee \& H.Tanaka. (E-G) Ferocia ninae Van de Vijver \& Houk. (H) Staurosirella pinnata (Ehrenberg) D.M.Williams \& Round. (I-K) Achnanthes tumescens A.R.Sherwood \& R.L.Lowe. (L-N) Navicula sp. (O-Q) Cavinula lapidosa (Krasske) Lange-Bertalot. (R-U) Geissleria ignota (Krasske) Lange-Bertalot \& Metzeltin. (V-Y) Sellaphora atomoides (Grunow) Wetzel \& Van de Vijver. (Z-AC) Sellaphora saugerresii (Desm.) Wetzel \& D.G.Mann. (AD-AF) Halamphora montana (Krasske) Levkov. (AG-AJ) Halamphora normanii (Rabenhorst) Levkov. (AK-AN) Tryblionella debilis Arnott ex O'Meara. (AO, AP) Pinnularia borealis Ehrenberg. (AR) Nitzschia vitrea G.Norman. (AS-AU) Fallacia insociabilis (Krasske) D.G.Mann. (AV-AA) Humidophila sp. (AB-BG) Humidophila cf. pantropica (Lange-Bertalot) Lowe, Kociolek, J.R.Johansen, Van de Vijver, Lange-Bertalot \& Kopalová. (BH, BI) Humidophila gallica (W.Smith) Lowe, Kociolek, Q.You, Q.Wang \& Stepanek. (BJ-BP) Humidophila deceptioensis Kopalová, Zidarova \& Van de Vijver. (BQ-BT) Humidophila contenta (Grunow) Lowe, Kociolek, J.R.Johansen, Van de Vijver, Lange-Bertalot \& Kopalová. (BU-CX) Nitzschia cf. microcephala Grunow. (CY-CB) Nitzschia inconspicua Grunow. (CC-CE) Denticula subtilis Grunow. Scale bar: $10 \mu \mathrm{m}$. 


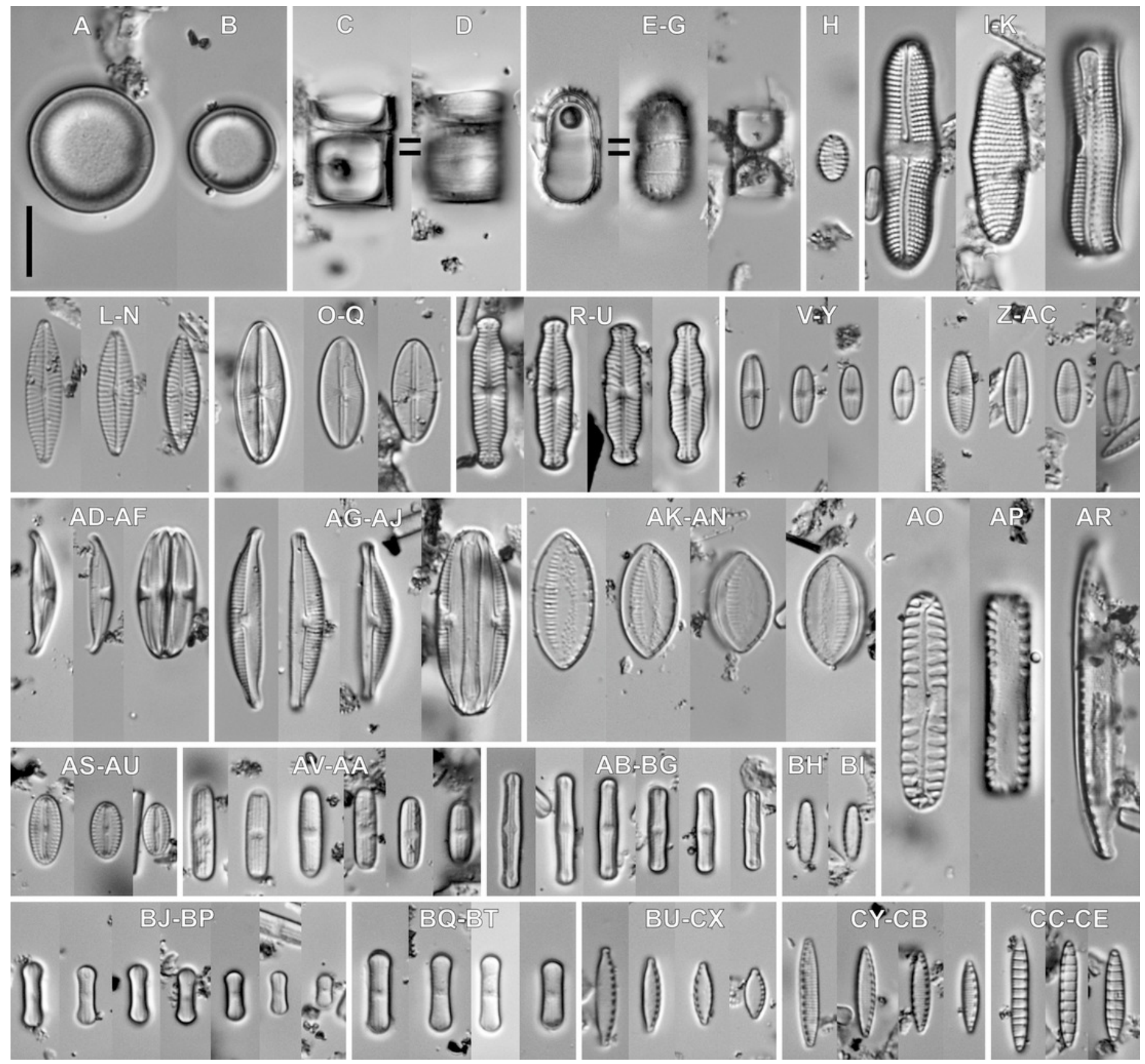




\section{Figure 7}

SEM images for small-celled diatoms from the assemblage studied.

(A) Humidophila cf. pantropica (Lange-Bertalot) Lowe, Kociolek, J.R.Johansen, Van de Vijver, Lange-Bertalot \& Kopalová. (B) Humidophila sp. (C) Humidophila gallica (W.Smith) Lowe, Kociolek, Q.You, Q.Wang \& Stepanek. (D) Humidophila contenta (Grunow) Lowe, Kociolek, J.R.Johansen, Van de Vijver, Lange-Bertalot \& Kopalová. (E, F) Humidophila deceptioensis Kopalová, Zidarova \& Van de Vijver (E: external view, F: internal view). (G) Sellaphora saugerresii (Desm.) Wetzel \& D.G.Mann. (G) Denticula subtilis Grunow. (I) Nitzschia cf. microcephala Grunow. (J) Nitzschia inconspicua Grunow. Scale bar: (A, B, G-J) $5 \mu \mathrm{m}$, (C) $3 \mu \mathrm{m}$, (D-F) $4 \mu \mathrm{m}$. 

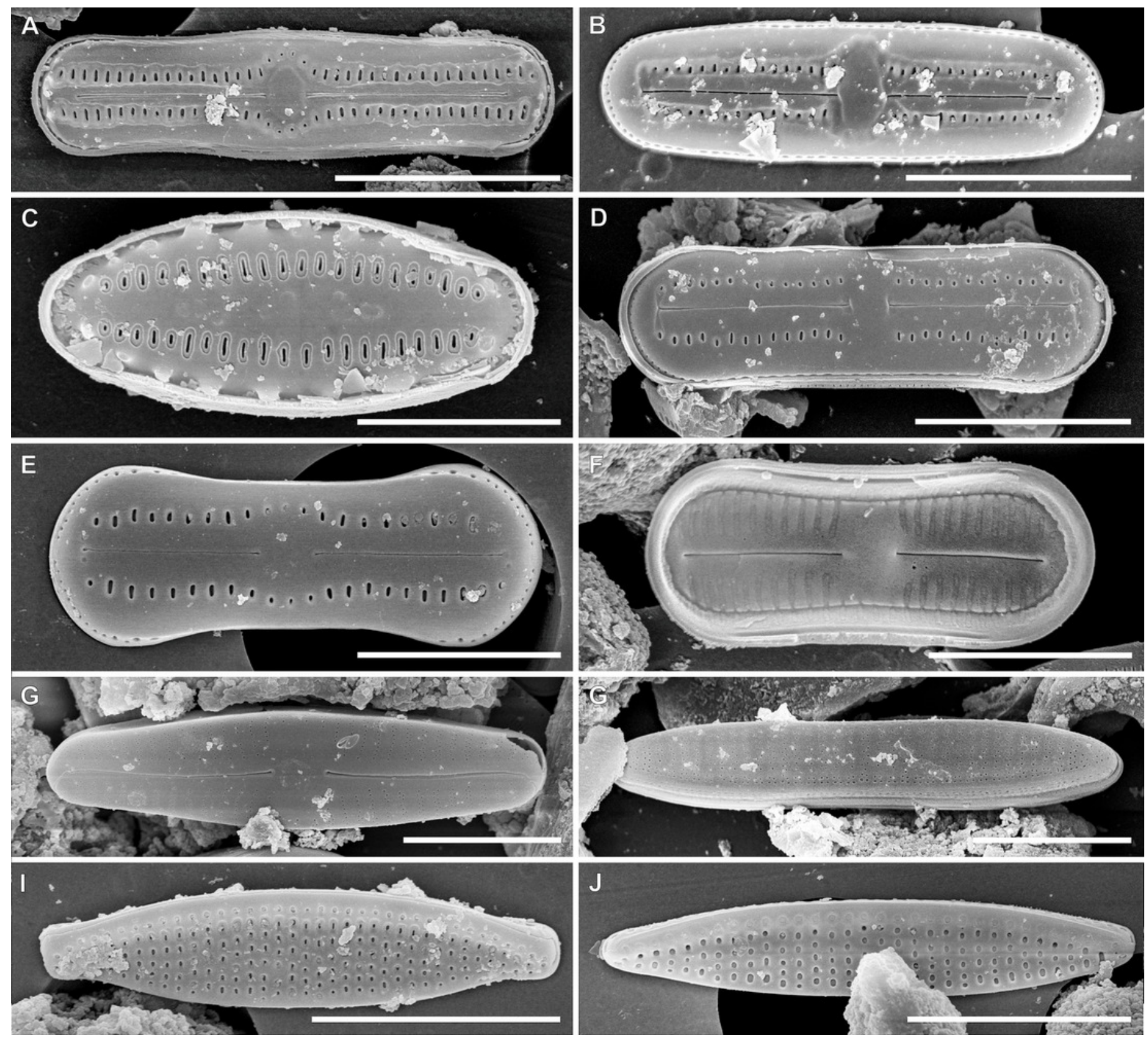